\title{
Chapter 13 \\ Nuclear Radiation Levels in the Forest at Minamisoma, Fukushima Prefecture
}

\author{
Iwao Uehara, Tomoko Seyama, Fumio Eguchi, Ryuichi Tachibana, \\ Yukito Nakamura, and Hiroya Ohbayashi
}

\begin{abstract}
The Great East Japan Earthquake occurred on March 11, 2011, and 4 days later, the Tokyo Electric Power Company (TEPCO) Fukushima No. 1 Nuclear Power Plant accident happened. The accident caused serious nuclear pollution damage for the Fukushima area, and it was reported that the forest area had received especially severe damage. However, its present situation has not been studied yet, nor has reforestation been planned. Therefore, we surveyed the amount of nuclear radiation at the forest of Minamisoma City where the amount of radiation has been reported as extremely high. We set several survey plots in the forest and surveyed the radiation amount of leaves, branches, wood (bark and stem), soil, litter interception, and irrigation water. The surveying results showed nuclear pollution was not spread equally in the Minamisoma forest, but in several "hot spots," that some litter interception indicated high radiation amounts, the extraction rates from bark to xylem were different between conifers and deciduous trees and between standing living trees and mushroom bed logs, and radioactive cesium was not detected in transpiration water.
\end{abstract}

Keywords Nuclear radiation $\bullet$ Minamisoma City $\bullet$ Fukushima $\bullet$ Forest

\subsection{Introduction}

The Great East Japan Earthquake occurred on March 11, 2011. It was followed during the next 4 days by the Tokyo Electric Power Company (TEPCO) Fukushima Daiichi Nuclear Power Station accident. The accident caused serious nuclear pollution damage in the Fukushima area, and it has been reported that forested areas sustained especially severe radiation damage (Uehara et al. 2014; Kaneko et al. 2013; Nonaka et al. 2012; Schreurs and Yoshida 2013; Takeuchi 2011). However, no

I. Uehara $(\bowtie) \bullet$ T. Seyama $\bullet$ F. Eguchi $\bullet$ R. Tachibana $\bullet$ Y. Nakamura $\bullet$ H. Ohbayashi Department of Forest Science, Tokyo University Agriculture,

1-1-1 Sakuragaoka, Setagaya-ku, Tokyo 156-8502, Japan

e-mail: i1uehara@nodai.ac.jp 
definitive research has yet been undertaken into the consequences of the accident, and no plans exist for rehabilitating the forest. This study therefore surveyed the nuclear radiation levels in the forest at the city of Minamisoma, where radiation levels were reported to be extremely high (Ministry of Education, Culture, Sports, Science and Technology 2011).

\subsection{Methods}

We identified six survey areas in the Minamisoma forest (Fig. 13.1) and surveyed the radioactive cesium levels of leaves, branches, trunks (bark and xylem), soil, litter layer, and irrigation water. We also surveyed transpiration water from the leaves of trees. We used a radiation surveying system and survey meter from Hitachi Aloka Medical and a germanium detector system from CANBERRA Industries. The survey lasted from April 2012 to July 2013.

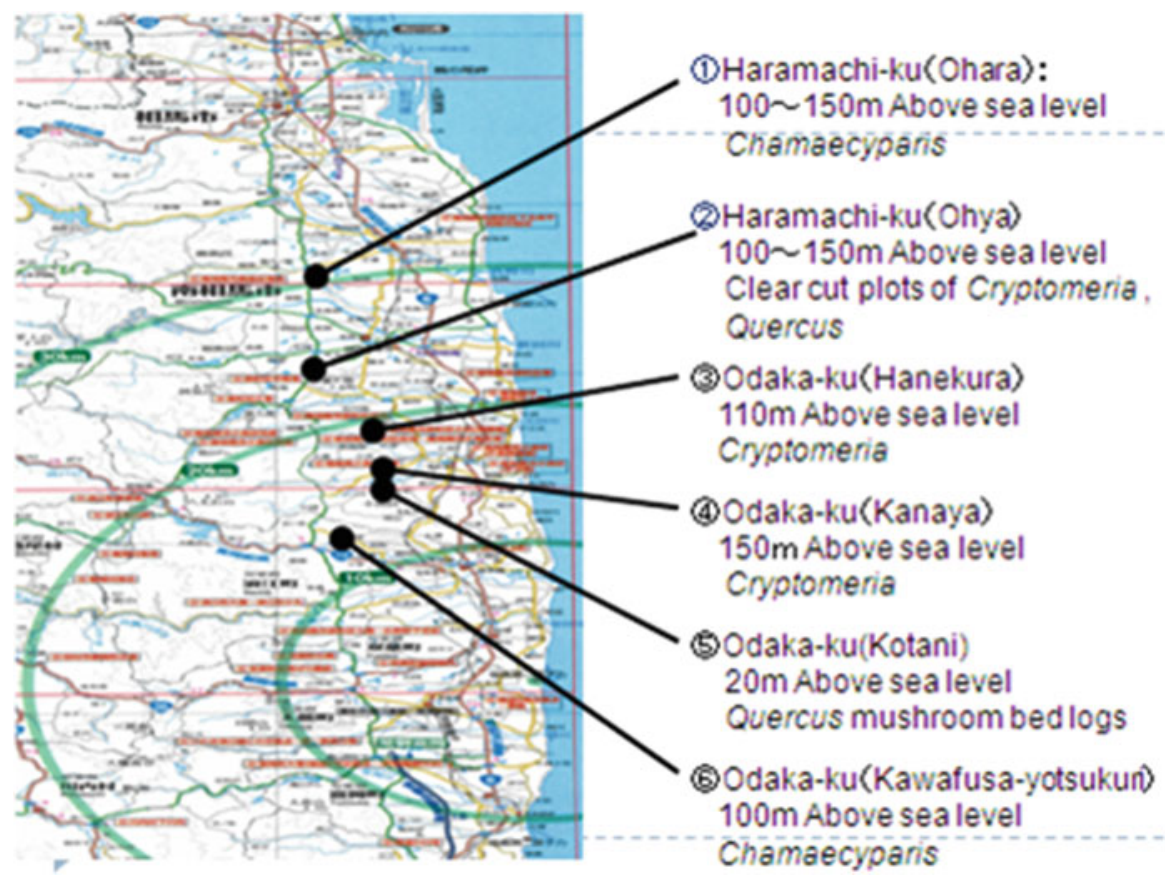

Fig. 13.1 Survey areas in Minamisoma 


\subsection{Results}

\subsubsection{Forest Soil}

Radiation levels found in the soil around conifers (Chamaecyparis and Cryptomeria) were high, whereas levels around deciduous Quercus were lower. The radiation levels in clear-cut plots were lower than in the stands (Table 13.1).

\subsubsection{Litter Layer}

Some areas indicated extremely high levels of radiation. The data for Tetsuzan Dam in Haramachi and the Chamaecyparis stand were especially high (Table 13.2). In terms of geographic features, the former is in a valley and the latter is in a flat field without barrier materials (Figs. 13.2 and 13.3). It has already been reported that Cryptomeria and Pinus are sensitive to radiation, and the litter layer is where radioactive cesium is easily accumulated (Yoshida 2012). In addition, it was reported in the same work that evergreen trees absorb more radioactive cesium than deciduous trees. Our survey data corroborated these findings, indicating that radiation levels in evergreen conifer wood were higher than in deciduous wood.

Table 13.1 Radioactive cesium (Cs) detected at 5-cm depth in forest soil (Bq/kg)

\begin{tabular}{|c|c|c|c|c|}
\hline Area & Altitude (m) & ${ }^{134} \mathrm{Cs}$ & ${ }^{137} \mathrm{Cs}$ & Total Cs \\
\hline Haramachi-ku & \multirow[t]{2}{*}{135} & \multirow[t]{2}{*}{13,600} & \multirow[t]{2}{*}{19,100} & \multirow[t]{2}{*}{32,700} \\
\hline Chamaecyparis stand (25 years) & & & & \\
\hline Haramachi-ku & \multirow[t]{2}{*}{120} & \multirow[t]{2}{*}{5,250} & \multirow[t]{2}{*}{7,460} & \multirow[t]{2}{*}{12,710} \\
\hline Chamaecyparis stand (25 years) & & & & \\
\hline Haramachi-ku & \multirow[t]{2}{*}{20} & \multirow[t]{2}{*}{3,220} & \multirow[t]{2}{*}{5,550} & \multirow[t]{2}{*}{8,770} \\
\hline Quercus acutissima stand & & & & \\
\hline Haramachi-ku & \multirow[t]{2}{*}{130} & \multirow[t]{2}{*}{1,380} & \multirow[t]{2}{*}{1,990} & \multirow[t]{2}{*}{3,360} \\
\hline Clear-cut plot of Quercus serrata & & & & \\
\hline Haramachi-ku & \multirow[t]{2}{*}{120} & \multirow[t]{2}{*}{78} & \multirow[t]{2}{*}{177} & \multirow[t]{2}{*}{255} \\
\hline Clear-cut plot of Cryptomeria & & & & \\
\hline Haramachi-ku & \multirow[t]{2}{*}{0} & \multirow[t]{2}{*}{68} & \multirow[t]{2}{*}{143} & \multirow[t]{2}{*}{211} \\
\hline Minamiebi seaside & & & & \\
\hline Odaka-ku & \multirow[t]{2}{*}{20} & \multirow[t]{2}{*}{14,700} & \multirow[t]{2}{*}{22,300} & \multirow[t]{2}{*}{37,000} \\
\hline Cryptomeria stand (40 years) & & & & \\
\hline
\end{tabular}


Table 13.2 Radioactive cesium detected in litter layer $(\mathrm{Bq} / \mathrm{kg})$

\begin{tabular}{|c|c|c|c|c|}
\hline Area & Altitude $(\mathrm{m})$ & ${ }^{134} \mathrm{Cs}$ & ${ }^{137} \mathrm{Cs}$ & Total Cs \\
\hline Haramachi-ku & \multirow[t]{2}{*}{280} & \multirow[t]{2}{*}{78,300} & \multirow[t]{2}{*}{143,000} & \multirow[t]{2}{*}{221,300} \\
\hline Tetsusan Dam & & & & \\
\hline Haramachi-ku & \multirow[t]{2}{*}{120} & \multirow[t]{2}{*}{14,180} & \multirow[t]{2}{*}{32,400} & \multirow[t]{2}{*}{46,580} \\
\hline Cryptomeria stand (40 years) & & & & \\
\hline Haramachi-ku & \multirow[t]{2}{*}{80} & \multirow[t]{2}{*}{5,340} & \multirow[t]{2}{*}{10,800} & \multirow[t]{2}{*}{16,140} \\
\hline City museum: Abies densiflora stand & & & & \\
\hline Haramachi-ku & \multirow[t]{2}{*}{120} & \multirow[t]{2}{*}{3,830} & \multirow[t]{2}{*}{6,680} & \multirow[t]{2}{*}{10,510} \\
\hline Chamaecyparis stand (20 years) & & & & \\
\hline Odaka-ku & \multirow[t]{2}{*}{50} & \multirow[t]{2}{*}{113,000} & \multirow[t]{2}{*}{177,000} & \multirow[t]{2}{*}{290,000} \\
\hline Chamaecyparis stand (15 years) & & & & \\
\hline Odaka-ku & \multirow[t]{2}{*}{120} & \multirow[t]{2}{*}{53,200} & \multirow[t]{2}{*}{93,600} & \multirow[t]{2}{*}{146,800} \\
\hline Cryptomeria stand (40 years) & & & & \\
\hline Odaka-ku & \multirow[t]{2}{*}{100} & \multirow[t]{2}{*}{11,300} & \multirow[t]{2}{*}{19,200} & \multirow[t]{2}{*}{30,500} \\
\hline Cryptomeria stand (40 years) & & & & \\
\hline Odaka-ku & \multirow[t]{2}{*}{120} & \multirow[t]{2}{*}{7,380} & \multirow[t]{2}{*}{12,300} & \multirow[t]{2}{*}{19,680} \\
\hline Meeting house & & & & \\
\hline Odaka-ku & \multirow[t]{2}{*}{110} & \multirow[t]{2}{*}{697} & \multirow[t]{2}{*}{1,100} & \multirow[t]{2}{*}{1,797} \\
\hline Horse Park: Prunus, Zelkoba & & & & \\
\hline
\end{tabular}

Fig. 13.2 A 15-year

Chamaecyparis stand in Odaka-ku

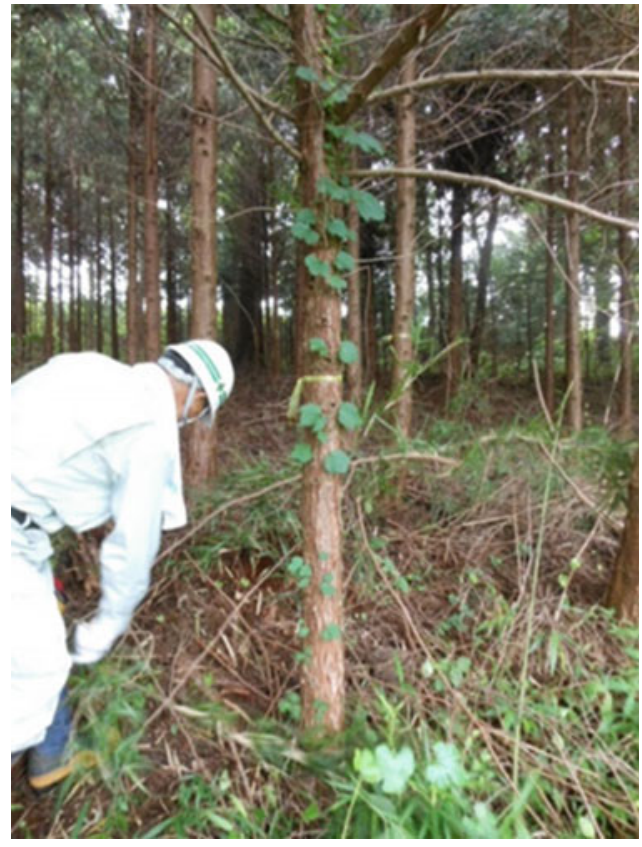


Fig. 13.3 Air radiation is $11-13 \mu \mathrm{Sv}$ at 15 -year Chamaecyparis stand in Odaka-ku

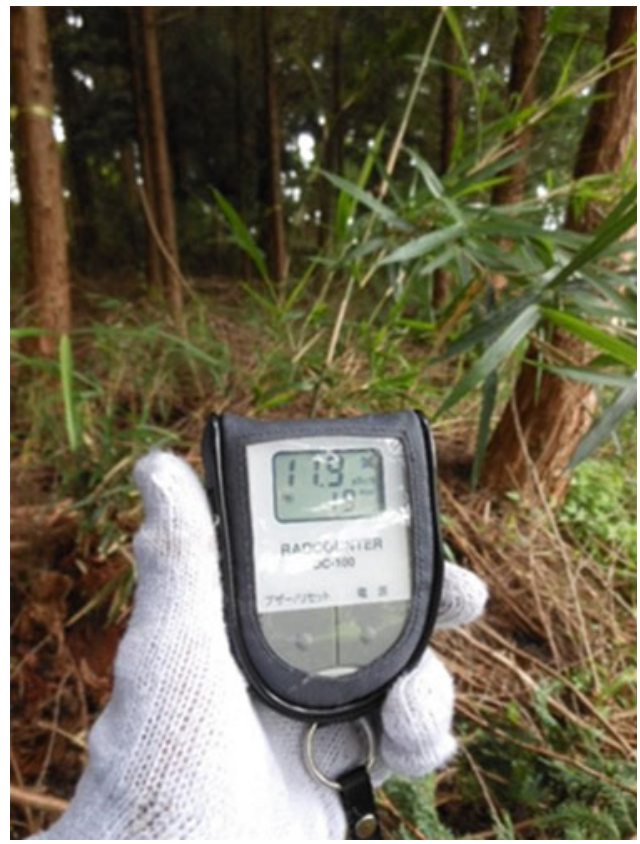

\subsubsection{Branches and Leaves}

The levels of radioactive cesium varied considerably, but the levels in conifers and evergreen trees were higher than in deciduous trees (Table 13.3).

\subsubsection{Bark and Wood of Standing Trees}

The levels of radiation in conifers were higher than in deciduous trees (Table 13.4).

\subsubsection{Quercus serrata Mushroom Bed Logs Outdoors}

Fukushima Prefecture, and the city of Minamisoma in particular, are key locations for production of mushroom bed $\log s$ and are home to many mushroom farmers. After the nuclear accident, however, many bed logs were abandoned outdoors (Fig. 13.4). The levels of radiation found in these bed logs varied greatly, but the levels found in xylem were approximately around $60 \%$ of the levels found in bark (Table 13.5). 
Table 13.3 Radioactive cesium detected in branches and leaves $(\mathrm{Bq} / \mathrm{kg})$

\begin{tabular}{|c|c|c|c|c|}
\hline Area & Altitude (m) & ${ }^{134} \mathrm{Cs}$ & ${ }^{137} \mathrm{Cs}$ & Total Cs \\
\hline Haramachi-ku & \multirow[t]{2}{*}{120} & \multirow[t]{2}{*}{1,930} & \multirow[t]{2}{*}{3,280} & \multirow[t]{2}{*}{5,210} \\
\hline Cryptomeria (40 years) & & & & \\
\hline Haramachi-ku & \multirow[t]{2}{*}{120} & \multirow[t]{2}{*}{2,130} & \multirow[t]{2}{*}{3,010} & \multirow[t]{2}{*}{5,140} \\
\hline Cephalotaxus harringtonia & & & & \\
\hline Haramachi-ku & \multirow[t]{2}{*}{120} & \multirow[t]{2}{*}{1,080} & \multirow[t]{2}{*}{2,450} & \multirow[t]{2}{*}{3,530} \\
\hline Quercus myrsinifolia & & & & \\
\hline Haramachi-ku & \multirow[t]{2}{*}{120} & \multirow[t]{2}{*}{1,270} & \multirow[t]{2}{*}{1,690} & \multirow[t]{2}{*}{2,960} \\
\hline Carpinus tschonoskii & & & & \\
\hline Haramachi-ku & \multirow[t]{2}{*}{120} & \multirow[t]{2}{*}{1,030} & \multirow[t]{2}{*}{1,560} & \multirow[t]{2}{*}{2,590} \\
\hline Zanthoxylum piperitum & & & & \\
\hline Haramachi-ku & \multirow[t]{2}{*}{120} & \multirow[t]{2}{*}{337} & \multirow[t]{2}{*}{814} & \multirow[t]{2}{*}{1,151} \\
\hline Orixa japonica & & & & \\
\hline Haramachi-ku & \multirow[t]{2}{*}{120} & \multirow[t]{2}{*}{ ND } & \multirow[t]{2}{*}{171} & \multirow[t]{2}{*}{171} \\
\hline Padus grayana & & & & \\
\hline Odaka-ku & \multirow[t]{2}{*}{50} & \multirow[t]{2}{*}{14,500} & \multirow[t]{2}{*}{21,500} & \multirow[t]{2}{*}{36,000} \\
\hline Chamaecyparis (15 years) & & & & \\
\hline Odaka-ku & \multirow[t]{2}{*}{120} & \multirow[t]{2}{*}{8,030} & \multirow[t]{2}{*}{19,000} & 27,030 \\
\hline Cryptomeria (40 years) & & & & \\
\hline Odaka-ku & 50 & 4,180 & 6,030 & 10,210 \\
\hline Callicarpa japonica & & & & \\
\hline Odaka-ku & 50 & 1,984 & 3,419 & 5,403 \\
\hline Acer palmatum & & & & \\
\hline
\end{tabular}

Table 13.4 Radioactive cesium detected in the bark and wood of standing trees $(\mathrm{Bq} / \mathrm{kg})$

\begin{tabular}{|c|c|c|c|c|c|c|c|c|}
\hline & \multirow{2}{*}{$\begin{array}{l}\text { Altitude } \\
\text { (m) }\end{array}$} & \multicolumn{3}{|l|}{ Bark } & \multicolumn{3}{|c|}{ Xylem } & \multirow[b]{2}{*}{ Xylem/bark } \\
\hline & & ${ }^{134} \mathrm{Cs}$ & ${ }^{137} \mathrm{Cs}$ & Total Cs & ${ }^{134} \mathrm{Cs}$ & ${ }^{137} \mathrm{Cs}$ & Total Cs & \\
\hline Haramachi-ku & \multirow[t]{2}{*}{60} & \multirow[t]{2}{*}{2,187} & \multirow[t]{2}{*}{2,275} & \multirow[t]{2}{*}{4,462} & \multirow[t]{2}{*}{1,358} & \multirow[t]{2}{*}{1,654} & \multirow[t]{2}{*}{3,012} & \multirow[t]{2}{*}{$67.5 \%$} \\
\hline Quercus serrata & & & & & & & & \\
\hline Odaka-ku & \multirow[t]{2}{*}{20} & \multirow[t]{2}{*}{233} & \multirow[t]{2}{*}{249} & \multirow[t]{2}{*}{482} & \multirow[t]{2}{*}{144} & \multirow[t]{2}{*}{150} & \multirow[t]{2}{*}{294} & \multirow[t]{2}{*}{$61.0 \%$} \\
\hline $\begin{array}{l}\text { Quercus serrata } \\
\text { no. } 1\end{array}$ & & & & & & & & \\
\hline Odaka-ku & \multirow[t]{2}{*}{20} & \multirow[t]{2}{*}{362} & \multirow[t]{2}{*}{341} & \multirow[t]{2}{*}{703} & \multirow[t]{2}{*}{157} & \multirow[t]{2}{*}{184} & \multirow[t]{2}{*}{341} & \multirow[t]{2}{*}{$48.5 \%$} \\
\hline $\begin{array}{l}\text { Quercus serrata } \\
\text { no. } 2\end{array}$ & & & & & & & & \\
\hline Odaka-ku & \multirow[t]{2}{*}{20} & \multirow[t]{2}{*}{719} & \multirow[t]{2}{*}{1,213} & \multirow[t]{2}{*}{1,932} & \multirow[t]{2}{*}{4,258} & \multirow[t]{2}{*}{762} & \multirow[t]{2}{*}{5,020} & \multirow[t]{2}{*}{$63.1 \%$} \\
\hline $\begin{array}{l}\text { Quercus serrata } \\
\text { no. } 3\end{array}$ & & & & & & & & \\
\hline Odaka-ku & \multirow[t]{2}{*}{50} & \multirow[t]{2}{*}{13,418} & 15,418 & 28,836 & 7,619 & 9,418 & 17,037 & $59.0 \%$ \\
\hline Quercus serrata & & & & & & & & \\
\hline
\end{tabular}


Fig. 13.4 Abandoned Quercus serrata mushroom bed logs in Odaka-ku

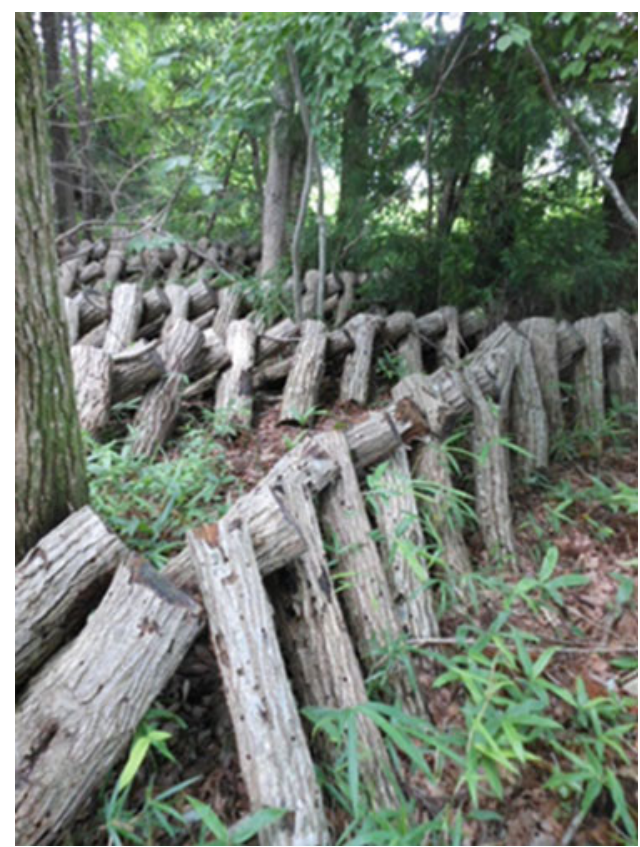

Table 13.5 Radioactive cesium detected in Quercus serrata mushroom bed logs outdoors (Bq/kg)

\begin{tabular}{|c|c|c|c|c|c|c|c|c|}
\hline & \multirow{2}{*}{$\begin{array}{l}\text { Altitude } \\
(\mathrm{m})\end{array}$} & \multicolumn{3}{|l|}{ Bark } & \multicolumn{3}{|c|}{ Xylem } & \multirow[b]{2}{*}{ Xylem/bark } \\
\hline & & ${ }^{134} \mathrm{Cs}$ & ${ }^{137} \mathrm{Cs}$ & Total Cs & ${ }^{134} \mathrm{Cs}$ & ${ }^{137} \mathrm{Cs}$ & Total Cs & \\
\hline Haramachi-ku & \multirow[t]{2}{*}{60} & \multirow[t]{2}{*}{2,187} & \multirow[t]{2}{*}{2,275} & \multirow[t]{2}{*}{4,462} & \multirow[t]{2}{*}{1,358} & \multirow[t]{2}{*}{1,654} & \multirow[t]{2}{*}{3,012} & \multirow[t]{2}{*}{$67.5 \%$} \\
\hline Quercus serrata & & & & & & & & \\
\hline Odaka-ku & \multirow[t]{2}{*}{20} & \multirow[t]{2}{*}{233} & \multirow[t]{2}{*}{249} & \multirow[t]{2}{*}{482} & \multirow[t]{2}{*}{144} & \multirow[t]{2}{*}{150} & \multirow[t]{2}{*}{294} & \multirow[t]{2}{*}{$61.0 \%$} \\
\hline $\begin{array}{l}\text { Quercus serrata } \\
\text { no. } 1\end{array}$ & & & & & & & & \\
\hline Odaka-ku & \multirow[t]{2}{*}{20} & \multirow[t]{2}{*}{362} & \multirow[t]{2}{*}{341} & \multirow[t]{2}{*}{703} & \multirow[t]{2}{*}{157} & \multirow[t]{2}{*}{184} & \multirow[t]{2}{*}{341} & \multirow[t]{2}{*}{$48.5 \%$} \\
\hline $\begin{array}{l}\text { Quercus serrata } \\
\text { no. } 2\end{array}$ & & & & & & & & \\
\hline Odaka-ku & \multirow[t]{2}{*}{20} & \multirow[t]{2}{*}{719} & \multirow[t]{2}{*}{1,213} & \multirow[t]{2}{*}{1,932} & \multirow[t]{2}{*}{4,258} & \multirow[t]{2}{*}{762} & \multirow[t]{2}{*}{5,020} & \multirow[t]{2}{*}{$63.1 \%$} \\
\hline $\begin{array}{l}\text { Quercus serrata } \\
\text { no. } 3\end{array}$ & & & & & & & & \\
\hline Odaka-ku & \multirow[t]{2}{*}{50} & \multirow[t]{2}{*}{13,418} & 15,418 & 28,836 & 7,619 & 9,418 & 17,037 & $59.0 \%$ \\
\hline Quercus serrata & & & & & & & & \\
\hline
\end{tabular}

\subsubsection{Herbaceous Vegetation and Sprouts in Clear-Cut Plots}

We also studied herbaceous plants and sprouts that germinated in the spring of 2012. With the exception of Lamiaceae, these data show lower radiation levels than those for trees (Table 13.6). 
Table 13.6 Radioactive cesium detected in herbaceous vegetation, flowers, and sprouts in clearcut plots $(\mathrm{Bq} / \mathrm{kg})$

\begin{tabular}{l|l|l|l}
\hline & ${ }^{134} \mathrm{Cs}$ & ${ }^{137} \mathrm{Cs}$ & Total Cs \\
\hline Follopia japonica & ND & ND & ND \\
\hline Macleoya cordata & ND & ND & ND \\
\hline Lamiaceae & 3,320 & 4,720 & 8,040 \\
\hline Male flower of Castanea crenata & 306 & 553 & 859 \\
\hline Sprout of Quercus serrata no. 1 & 663 & 1,000 & 1,663 \\
\hline Sprout of Quercus serrata no. 2 & 266 & 281 & 547 \\
\hline Sprout of Quercus serrata no. 3 & 257 & 295 & 552 \\
\hline
\end{tabular}

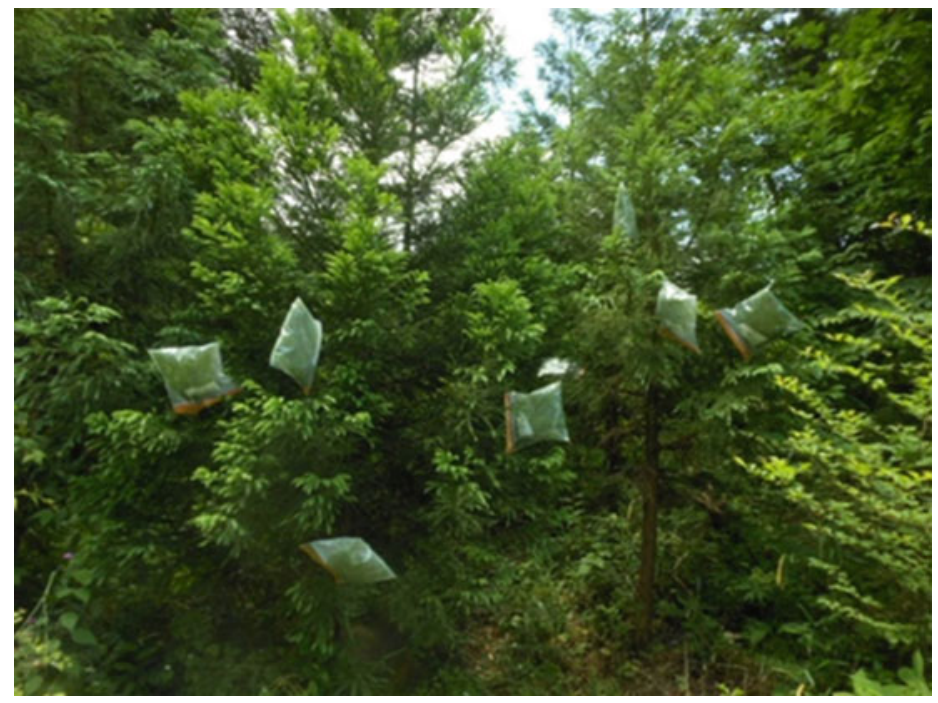

Fig. 13.5 Trapping transpiration water from the leaves of young Cryptomeria japonica using plastic bags in June 2013

\subsubsection{Transpiration Water and Irrigation Water}

We also surveyed transpiration water from the leaves of trees (Fig. 13.5). The leaves of 8-year-old and 40-year-old Cryptomeria trees were wrapped in plastic bags $\left(27 \mathrm{~cm}^{2}\right)$ for $24 \mathrm{~h}$ on June 13, 2013. Samples of $20 \mathrm{ml}$ were analyzed, but radioactive cesium was not detected. This result suggests that the possibility of secondary radioactive contamination from living standing trees may be low.

We also surveyed irrigation water at some locations in the Haramachi and Odaka areas, but radioactive cesium was not detected. 


\subsection{Discussion}

The foregoing results suggest these points.

1. Levels of nuclear radiation in Minamisoma were influenced mainly by the city's location to the northwest of the Fukushima Daiichi Nuclear Power Station and the prevailing wind direction on March 14, 2011.

2. High levels of radiation were distributed unevenly over valleys or fields without barriers.

3. In general, the nuclear pollution was not evenly distributed, but was in the form of "hot spots."

4. The litter layer in some areas showed extremely high levels of radiation.

5. Abandoned forests and multi-layered forests indicated high levels of radiation; levels were lower in clear-cut plots.

6. The extraction rates from bark to xylem were different between conifers and deciduous trees. They were also different between standing living trees and mushroom bed logs (Quercus serrata).

7. Levels of radiation found in mushroom bed logs abandoned in the outdoors varied greatly.

8. Radiation levels of herbaceous plants and Quercus serrata sprouts that germinated in the spring of 2012 were clearly lower than those of trees in stands.

9. No radioactive cesium was detected in transpiration water, suggesting that the probability of secondary radioactive contamination from living standing trees may be low.

Some attempts need to be made to decontaminate forest areas in Fukushima Prefecture, but the prefecture's forests are extensive and comprise geographically complex terrain, so it is not practically possible to decontaminate them all. However, we propose creating small clear-cut examination plots (Fig. 13.6) in locations where soil erosion cannot occur within the forests. Our survey data showed that the radiation levels of herbaceous vegetation and Quercus serrata sprouts germinated in the clear-cut plot in spring 2012 were clearly lower than those of trees in stands. One practical method, therefore, would be to promote growth of the newly germinated plants and sprouts in such plots while continuing to survey radioactive cesium levels.

\subsection{Conclusion}

The results of this study showed that there were still forests in which radioactive cesium levels were high. The half-life of cesium is more than 30 years, and forest regeneration also takes a long time. We should therefore continue to collect data on radioactive cesium and the dynamics of vegetative regeneration. 

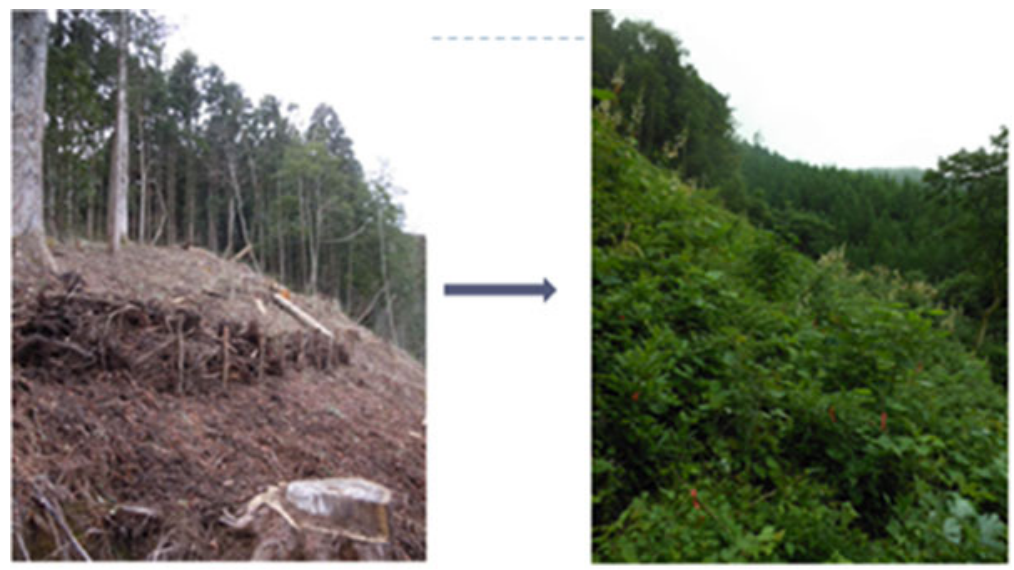

Dec.of 2011

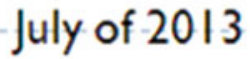

Fig. 13.6 Clear-cut plot within a Cryptomeria japonica stand in Haramachi, Minamisoma

Acknowledgments We wish to express our appreciation to Eihachi Horiuchi, chief of Soma's regional forestry cooperative, who helped with our survey, and Yoichi Takeyama, who provided us with experimental forest plots and guided us around Minamisoma's forests.

Open Access This chapter is distributed under the terms of the Creative Commons Attribution Noncommercial License, which permits any noncommercial use, distribution, and reproduction in any medium, provided the original author(s) and source are credited.

\section{References}

Kaneko S et al (2013) The change of air dose rate in the forest contaminated with radioactive materials by the accident at Tokyo Electric Power Company's Fukushima Daiichi Nuclear Power Plant. Kanto J For Res 64(2):37-40 (in Japanese)

Ministry of Education, Culture, Sports, Science and Technology (2011) Total cesium data on the ground surface. http://ramap.jmc.or.jp/map/eng/map.html (in Japanese)

Nonaka M, et al (2012) The dynamics of radioactive cesium in the wood. In: The 123th Japanese Forest Society annual meeting transaction (CD-R) (in Japanese)

Schreurs M, Yoshida F (2013) Fukushima: a political economic analysis of a nuclear disaster. Hokkaido University Press, Sapporo

Takeuchi K (2011) There has been still big unconvergence problems at Fukushima nuclear plant: it has come to show same condition of Chernobyl. Green Power 2011:24-25 (in Japanese)

Uehara I, et al (2014) Continued radiation research at Minamisoma City forest, Fukushima, from 2012 to 2014. In: 4th Kanto Forest Research meeting transactions (in Japanese)

Yoshida S (2012) The movement of radioactive fallout in the forest ecosystem: estimated condition and problems considered by past studies. For Sci 65:31-33 (in Japanese) 